DOI: $10.14451 / 2.124 .17$

\title{
АРИСТОТЕЛЕВА ПОЛИТИЯ КАК ИНСТРУМЕНТ КОНСТИТУИРОВАНИЯ СОЦИУМА: РЕАЛЬНОСТЬ ИЛИ УТОПИЯ?
}

\author{
(c) 2018 Даова Фатима Хазреталиевна \\ Институт права, экономики и финансов \\ Кабардино-Балкарский государственный университет имени Х.М. Бербекова \\ 360004, г. Нальчик, ул. Чернышевского, 173 \\ (c) 2018 Шаваева Диана Вячеславовна \\ Институт права, экономики и финансов \\ Кабардино-Балкарский государственный университет имени Х.М. Бербекова \\ 360004, г. Нальчик, ул. Чернышевского, 173 \\ (c) 2018 Литягина Алла Сергеевна \\ старший преподаватель \\ Институт права, экономики и финансов \\ Кабардино-Балкарский государственный университет имени Х.М. Бербекова \\ 360004, г. Нальчик, ул. Чернышевского, 173 \\ (c) 2018 Кокова Лиана Руслановна \\ доцент \\ Институт права, экономики и финансов \\ Кабардино-Балкарский государственный университет имени Х.М. Бербекова \\ 360004, г. Нальчик, ул. Чернышевского, 173 \\ (c) 2018 Куашев Артур Каншобиевич \\ Судья \\ Чегемский районный суд \\ Кабардино-Балкарская Республика
}

В статье дается историко-политологический анализ диспуту о лучшей форме государственного правления. На основе исследования предлагается выделить политию как универсальный медиум политической коммуникации власти и народа, представляющий собой симбиоз монархических и республиканских начал в форме правления. Путем рассуждений и результатов диалектического анализа был сделан вывод о возможности реализации концепта «аристотелевой диффузии» лучших сторон двух основных форм государственного правления для зарождения совершенно новой и прагматической формы.

Ключевые слова: государство, форма правления, монархия, республика, полития, Аристотель, народ, власть

Любое государство есть синтез его сущности, содержания и формы. Актуальность темы диктуется тем, что именно форма является способом существования и выражения государства. Под формой правления подразумевают организацию верховной государственной власти. Уже в античной философии формы правления стали объектом пристального и глубокого анализа и изучения. Античные мыслители выделили 6 возможных форм правления, из которых 3 «правильные» (монархия; аристократия; демократия) и 3 «неправильные» (тирания; олигархия; охлократия). А древнегреческий философ По-

либий даже составил преобразовательный цикл смены одной формы правления другой: монархия - тирания - аристократия - олигархия демократия - охлократия - и снова «по кругу» [1].

Долгое время данная классификация оставалась общепризнанной. Но философы Нового времени свели формы правления к трем основным: монархия, аристократия, демократия. Демаркация их на «правильные» и «неправильные» было признано субъективистским, относительным.

Однако впоследствии и эта классификация 
была признана ненаучной, так как в чистом, «стерильном» виде такие формы правления нигде не встречаются. Реальные формы правления имеют элементы и монархии (единоличный глава государства), и аристократии (представительный орган либо окружение правителя), и демократии (опора на поддержку населения в той или иной форме).

В связи с чем, в современной политической науке выделяют две формы государственного правления - монархию и республику.

Монархией можно назвать такое государство, где верховная власть принадлежит одному лицу, пользующемуся ею по собственному праву, которое не делегировано ему никакой другой властью, тогда как в республике единственным легитимным и правомерным носителем верховной власти или источником государственного суверенитета рассматривается именно народ [2].

Но какова же роль формы правления для государства и какая из них предпочтительнее? В античности этому вопросу придавалось принципиальное значение, поэтому практически все известные мыслители той эпохи выдвигали свой вариант «идеальной» формы государства.

В частности, обоснование «идеальной» смешанной формы правления - политии принадлежит Аристотелю, который глубоко и обстоятельно осветил данную идею в одном из своих трактатов. По мнению древнегреческого философа, полития - это конституционная умеренно монархическая демократия, руководители которой способны агрегировать свободу с порядком [3]. Синхронный анализ понятий «конституционная республика», «либеральная демократия» и «полития» указывает на их теоретическую гомогенность и частичную синонимичность. И, таким образом, проводя параллель с терминологией современной политической науки касающейся форм правления, необходимо отметить, что сущность данной формы заключается в соединении в себе лучших сторон республиканского и монархического оформления политико-правового института, но также в свободе от их крайностей и недостатков, иными словами, полития учитывает интересы вечных антагонистов - народа и власти. Из этого следует, что принципом создания правильной формы правления является эклектизм двух неправильных форм. Однако сам Аристотель не использовал в толковании «политии» понятие «республика», так как данный термин был введен авторами, в том числе и Леонардо Бруни, в употребление только в XV веке для описания немонархических государств.

В результате компаративного анализа двух основных форм правления, было выявлено, что к числу одиозных недостатков монархической формы правления можно отнести: политическую гетерономию, сакральное восприятие власти, культ ранга, фаворитизм, нарушение принципа паритета, аскеза политической воли народа, отсутствие электоральной системы, гласности, плюрализма и оппозиционности, но к числу главных преимуществ относятся способность быстро осуществлять долговременные государственные преобразования и тяга к интегрирующей аккумуляции. Главными индикаторами для определения степени полиархичности, соответственно, и достоинствами республиканской формы правления являются «эластичность» власти, а, следовательно, её ответственность перед народом, соблюдение широкого спектра прав человека, растворение личного начала и власти в коллективе, культ равенства и новаторства, утилитарное восприятие власти, выступление государства в роли свободного конгломерата, тяга к дифференцированной дискретности, атомизму, стихия конкуренции, разделение властей, действие механизма «сдержек и противовесов». В свою очередь, слабыми сторонами данного государственного обрамления выступают ограничение возможности принятия быстрых решений, а так же присутствие частичной плутократии.

Говоря о конституции, следует отметить, что это явление, не ограничивающее и замораживающее государство и общество зачаток, а начало созидательному, помощник правителю в его деятельности на благо государства как автономной корпорации. Политии, в свою очередь, свойственна основа конституционной системы, так как именно она создает условия для возникновения и развития персистентной системы демократии.

Таким образом, реализация данной политической идеи, нивелированной формы государства, вполне возможна, однако она напрямую зависит от совокупности экзогенных и эндогенных факторов: во-первых, от территориального масштаба государства, специализированная и концентрированная сила поддержания порядка и стабильности в обществе будет выше на небольшой территории; во-вторых, поскольку 
магистральной целью государства является осуществление добродетели необходимо исключение крайнего этатизма; и в - третьих, требуется абсолютное элиминирование черт коммунистической формации, «монолитного» единства при строительстве аристотелевой политии.

Говоря о политии, также следует уточнить, что в статье данная форма правления не дебатируется как «идеальная», подходящая любому государству, а рассматривается исключительно возможность ее воплощения, поскольку еще в XVIII веке французский мыслитель Монтескье утверждал, что форма государства должна соответствовать некоторым объективным факторам: географической среде, социально-экономическому устройству и т.п. В противном случае государство будет мешать нормальному функционированию, развитию и устойчивой экзистенции общества. Следовательно, наилучшая форма государства выводится не умозрительно, из аб- страктных постулатов, а из эмпирии, реальных обстоятельств. С возникновением исторического метода делается вывод о том, что форма государства непременно должна соответствовать исторически сложившимся обстоятельствам.

В свою очередь, достоинство политии, гибридной разновидности форм государственного правления, видится в агрегировании соответствующих принципов двух основных форм правления. Причем принципы данных форм правления объединяются в рамках одной формы в качестве различных начал властвования, правильная комбинация и надлежащее соотношение которых обеспечивают, по мысли древнегреческого мыслителя соответствующей концепции, политическую стабильность, справедливую меру и разумную форму участия народа в отправлении общегосударственных функций, и потому в корне реализуема.

\section{Библиографический список}

1. Васюта А.С. Три вида власти в древнегреческих политических трактатах // Вестник Тамбовского государственного университета. 2007. № 6. С. 2.

2. Ильин И.А. О монархии и республике. Т. 2. Москва. 2015.

3. Кулагин В.В., Лезина Е.П. «Афинская полития» Аристотеля о наилучшей форме правления // Приволжский научный вестник. 2016. № 4 С. 50-55.

4. «Политика» Аристотеля. Афинская полития. Москва. 2012. 62 с.

5. Беляева О.М. Полития как наилучшая форма правления, по Аристотелю // Вестник Пермского университета. Юридические науки. 2013. № 1. С. 19. 